\title{
Modelling the yield and profitability of intercropped walnut systems in Croatia
}

\author{
Helena Žalac $\mathbb{D} \cdot$ Paul Burgess • Anil Graves • Michail Giannitsopoulos • \\ Ivan Paponja $\cdot$ Brigita Popović • Vladimir Ivezić
}

Received: 24 December 2019/ Accepted: 11 March 2021/Published online: 24 March 2021

(C) The Author(s) 2021

\begin{abstract}
In Croatia, farmers are showing increasing interest in establishing walnut orchards for nut production on arable land due to higher anticipated net margins. One way to address the lack of profitability in the initial years when nut yields are low may be to plant arable intercrops. The anticipated impacts of this practice were assessed using a biophysical simulation model (Yield-SAFE) to determine the growth and yield of crops and trees in arable, orchard, and silvoarable systems, and an economic farm model (Farm-SAFE) was used to assess their profitability. The walnut orchard and the intercropped orchard systems were simulated assuming tree densities of 170,135 , and 100 trees $\mathrm{ha}^{-1}$, to determine the profitability and break-even date of the systems. The biophysical simulation predicted a decline in arable intercrop yields over time in all tree density scenarios. However, analysis of productivity of intercropped systems showed that intercropping was more
\end{abstract}

Supplementary Information The online version contains supplementary material available at https://doi.org/10.1007/ s10457-021-00611-z.

H. Žalac $(\bowtie) \cdot$ I. Paponja · B. Popović · V. Ivezić Faculty of Agrobiotechnical Sciences Osijek, University of J. J. Strossmayer in Osijek, 31000 Osijek, Croatia e-mail: hzalac@fazos.hr

P. Burgess - A. Graves · M. Giannitsopoulos Cranfield University, Cranfield MK43 OAL, Bedfordshire, UK productive than separate arable and walnut production for all tree density scenarios. From financial aspect, the return from intercropping helped to offset some of the initial orchard establishment costs and the arable intercrop remained profitable until the sixth year after tree planting. The modelling predicted that a system with 170 trees $\mathrm{ha}^{-1}$ that included intercropping for the first 6 years provided the greatest cumulative net margin after 20 years. The financial benefit of intercropping over the first 6 years opposed to monoculture walnut fruit production appeared to be consistent across the three tree densities studied. These results suggest that silvoarable agroforestry is profitable approach to establishing walnut orchards.

Keywords Bio-economic model $\cdot$ Silvoarable agroforestry · Intercropping · Walnut · Orchard

\section{Introduction}

Agroforestry, the combined production of woody perennials with crops (silvoarable) or livestock (silvopastoral), is a significant land use in Europe covering 15.4 million ha (den Herder et al. 2017), with the largest areas occurring in southern Europe. Although most of this area comprises silvopastoral systems, about 222,000 ha of agroforestry comprises the intercropping of arable crops with high value trees such as olives, nuts and fruit trees (den Herder et al. 
2017; Pantera et al. 2018). The addition of trees to arable systems offer a range of positive ecological effects such increased carbon sequestration (Palma et al. 2007b; Cong et al. 2015; Cardinael et al. 2017), enhanced biodiversity (Tsonkova et al. 2012; Torralba et al. 2016), reductions in nutrient loss and pesticide runoff (Pardon et al. 2017), and improvements of water availability and formation of positive microclimatic conditions (Quinkenstein et al. 2009).

The ecological benefits of tree planting on arable land, has encouraged the European Union to provide financial support for new agroforestry systems. Between 2007 and 2013, the EU Rural Development Programmes (RDPs) included Regulation 1698/2005 (The Council of the European Union 2005) which promoted the first establishment of new agroforestry systems on arable lands. However, a study in the UK, indicated that for most farmers, silvoarable systems need to show a financial advantage before they decide to switch from arable to silvoarable production (Graves et al. 2017). The exact financial and ecological benefits of a particular system, relative to arable cropping, will depend on a range of factors such as the climate, tree density, and choice of tree and crop species (Graves et al. 2007). One way to determine the anticipated impact of intercropping in a specific situation is to use a simulation model to predict the most important climate, soil, tree and crop effects and interactions in biophysical and financial terms. The biophysical Yield-SAFE model (van der Werf et al. 2007) and the bio-economic Farm-SAFE agroforestry model (Graves et al. 2011) were developed to inform European farmers and policy-makers on the potential of silvoarable agroforestry and to help reduce the uncertainties as part of the European Union sponsored SAFE project between 2001 and 2005. Both these models were further developed during the EU sponsored AGFORWARD project between 2014 and 2017 (Burgess and Rosati 2018). The developments include the creation of a climate database called CliPick (Palma 2017), and the integration of improved soil carbon algorithms within the Yield-SAFE model (Palma et al. 2018).

Previous research on the viability of silvoarable agroforestry in Europe has been largely based on the use of trees for timber production (Palma et al. 2007a; van der Werf et al. 2007; Graves et al. 2007, 2010). By contrast, there have been few publications on the biophysical and financial outputs of systems involving nut or fruit trees.

Walnut trees (Juglans species) produce nuts of high nutritional value which are rich in proteins, minerals and vitamins, and the oils are perceived to have health benefits (Ozkan and Koyuncu 2005). Walnuts are produced under a range of climate and soil conditions, but yields are reported to be highest in warm and temperate regions. Ahmad et al. (2018) report that optimal growing conditions included about 760-800 mm of well-distributed annual precipitation, deep, friable and permeable loam/silt loam or clay loam soils with a $\mathrm{pH}$ of 5.5-6.5, well supplemented with lime, and rich in humus. Walnut is sensitive to late spring and early autumn frosts as freezing temperatures kill the growing point of walnut trees and severely affects production. The recommended tree density depends on the climate, soil conditions and cultivars (Ahmad et al. 2018). In Croatia, walnuts are usually planted from a classic distance of $10 \times 10 \mathrm{~m}\left(100\right.$ trees $\left.\mathrm{ha}^{-1}\right)$ up to $5 \times 5(400$ trees $\mathrm{ha}^{-1}$ ) for intensive plantations with smaller, lateral varieties. Although grafted walnuts can bear their first fruits as early as the 3rd or 4th year, they do not give a significant yield before the 8th year. There is no published reference on walnut yields in Croatia, but according to the articles from Croatian Ministry of Agriculture advisory website, in full maturity, a wellmaintained plantation can yield 3.5-4 tons per hectare of walnuts in shell, although this again depends on cultivar and appropriate pruning of the canopy (Orah značajna voćna vrsta 2007). On the other hand, personal communication with expert organizations involved in walnut production in Croatia indicated that farmers are mostly cultivating terminal cultivars and that such grafted walnuts usually produce around $2 \mathrm{t} \mathrm{ha}^{-1}$ of nuts in shell by year 10-15 (NGO "Pupoljak", personal communication). The recommended practice is to initially shorten the seedlings in the spring at a height of 1.5-2 m, from where new apical and lateral buds will appear. Out of those lateral buds, three are typically selected and left to grow to form the future primary branches of a vase-shaped canopy. In the second and third year the pruning is directed to the formation of the trunk and canopy (Orah 2009). Walnut tree growth and production is typically enhanced by nitrogen application, with a recommended application of $100 \mathrm{~g} \mathrm{~N}$ per tree in the first year, and 200 and $400 \mathrm{~g} \mathrm{~N}$ per tree in year two and 
three. Also, after planting, application of $20-30 \mathrm{~kg}$ of manure is recommended around each seedling (Japundžić 2017).

Recently in Croatia, spurred by government subsidies, interest in raising walnut orchards has been growing. We observed a constant increase in the total area under walnut orchards since 2014, which was one of motives for our research. According to the latest data, it amounts 5554 ha and it is the second-largest area in fruit production, right after olive orchards (Croatian Bureau of Statistics 2018).

This study examines the predicted yield and financial impacts of establishing a semi-intensive intercropped walnut nut production systems in Croatia in Europe, as a transitional option from arable farming to fruit growing. The key questions are how does tree density affect the profitability of the arable crops and walnuts in three tree density scenarios, and how this compares with a pure arable system and pure orchard systems at the same density?

\section{Material and methods}

Systems description

Arable, walnut orchard and intercropped walnut orchard systems were simulated for 20 years period to explore its agronomic and financial returns. For arable component in the arable system and intercropped orchards, rotation of grain maize, barley and rapeseed was chosen, as common crop rotation in Croatia. Walnut input parameters were chosen considering cultivar with intermediary fructification. For walnut orchards and intercropped walnut orchards three tree density scenarios were simulated; 170, 135 and 100 trees $\mathrm{ha}^{-1}$ planted in a rectangular layout assuming distances between tree rows of 8,10 and $12 \mathrm{~m}$, respectively. Accordingly, crop alley widths in intercropped systems were selected to be 6,8 and $10 \mathrm{~m}$, leaving $1 \mathrm{~m}$ distance from trees on each side and giving the crop area of $75 \%, 80 \%$ and $83 \%$, respectively. In the walnut-only system, a grass cover was considered for system simulation.

Site description and climate

Đakovo in eastern Croatia (Fig. 1), an area with a continental climate of warm summers and cold winters, was chosen as the case study site for examining the agronomic and financial effects of different agroforestry designs. The altitude of the site is $111 \mathrm{~m}$, the soil type is loam and the effective soil depth is $1500 \mathrm{~mm}$. The mean air temperature is typically -2 to $0{ }^{\circ} \mathrm{C}$ in January, and $18-22{ }^{\circ} \mathrm{C}$ in July. The mean annual rainfall is $600-1000 \mathrm{~mm}$ and relatively evenly distributed throughout the year. In order to run the agroforestry simulation model, representative predicted daily weather data for the site in eastern Croatia for the period 2019-2039 was derived from CliPick (Palma 2017). Clipick weather data was validated by comparing its predicted data with the observed data from the local meteorological station.

Prediction of arable crop and walnut yields using Yield-SAFE

The prediction of the arable crop yields in an agroforestry system with the Yield-SAFE model firstly requires the calibration of the model for known arable crop yields in the absence of trees. Parameters for soil, tree and crop are shown in the supplementary material. The three parameters that were used for calibration were the amount of water transpired by the crop and tree, the crop harvest index and the management parameter-day of sowing. The parameterization and calibration of Yield-SAFE is explained in more details in van der Werf et al. (2007) and Graves et al. (2010). The assumed rotation for the arable system was a 3 year rotation of grain maize, barley and rapeseed. The typical planting months for these crops in Eastern Croatia are April for grain maize, early October for barley and late August for rapeseed. For calibration purposes, mean crop yields for these crops for the period 2013-2017 were derived from the Croatian Statistical Yearbook (Croatian Bureau of Statistics 2018), considering rotation starting with grain maize in 2013 and then compared with calculated rotation yields for the same years. After calibration, simulations were run for the period 2019-2039.

There is no published reference on walnut yields in Croatia. Personal communication with expert organizations involved in walnut production in Croatia and farmers cultivating mostly terminal cultivars indicated that grafted walnuts can start to yield nuts in year 4 and a typical yield of nuts with shells is around $2.5 \mathrm{tha}^{-1}$ by year 15 . Assuming 100-175 trees $\mathrm{ha}^{-1}$, this equate 


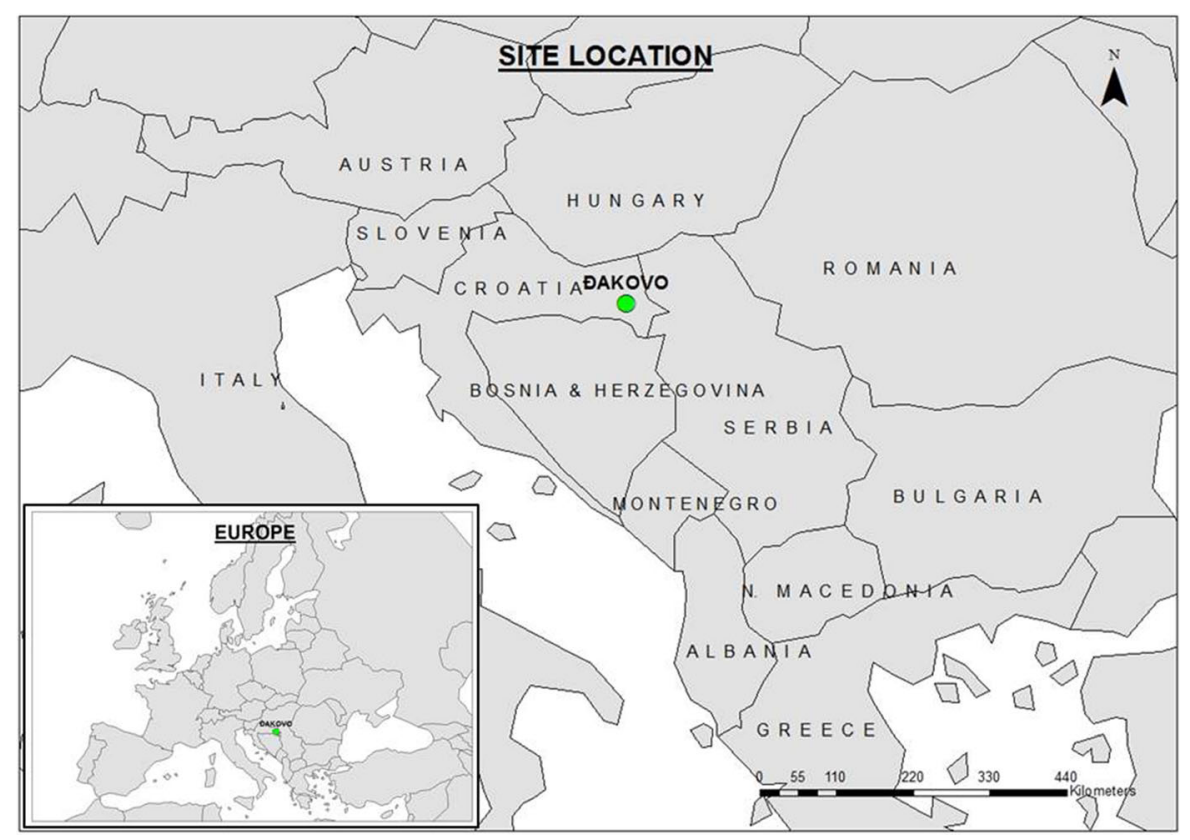

Fig. 1 Site location

to $15-25 \mathrm{~kg}$ per tree (NGO "Pupoljak", personal communication).

\section{Productivity analysis}

Arable crop yields in the intercropped orchards were simulated under tree densities of 170, 135 and 100 trees $\mathrm{ha}^{-1}$ with proportional crop areas of $75 \%, 80 \%$, and $83 \%$ respectively. Annual walnut fruit production was modelled for these tree densities for pure walnut and intercropped walnut orchards, and expressed in $\mathrm{kg}$ $\mathrm{ha}^{-1}$. From the crop and fruit yields, annual land equivalent ratios (LER) were estimated for each tree density scenarios. The land equivalent ratio is defined as the ratio of the area under monoculture production to the area under intercropping needed to give equal yields at the same management level (Ong and Kho 2015). It is calculated as the ratio of tree silvoarable nut yield to the tree monoculture nut yield plus the ratio of crop silvoarable yield to the crop monoculture yield as shown in Eq. 1:

$$
\begin{aligned}
\text { LER }= & \frac{\text { Tree silvoarable yield }}{\text { Tree monoculture yield }} \\
& +\frac{\text { Crop silvoarable yield }}{\text { Crop monoculture yield }}
\end{aligned}
$$

When LER $\leq 1$, there is no agronomic advantage of intercropping over sole cropping, but when LER is $>1$, production in the intercropped system is higher than in the separate sole crops. In our model the same number of trees were considered for tree silvoarable yields as for tree monoculture yield in order to investigate the productivity and profitability of the same walnut densities with and without arable cropping.

Financial analysis using Farm-SAFE

A financial model of the arable, walnut-only, and the intercropping systems was developed using the spreadsheet-based bio-economic model called FarmSAFE (Graves et al. 2011). Production costs (Tables 1 and 2) were obtained from interviews with farmers and complemented with cost calculations from the Croatian Agricultural and Forestry Advisory Service (Croatian Agricultural and Forestry Advisory Service 2018). The values of arable crops were from Croatian market prices (Table 2). The value of a green walnut picked in early summer is about $0.50 € \mathrm{~kg}^{-1}$. By contrast a walnut kernel sold without a shell at the end of summer can reach prices of up to $10 € \mathrm{~kg}^{-1}$. However, the mean price for kernels in their shell is 
Table 1 The assumed costs of walnut nut production
Table 2 The assumed revenue and costs associated with arable crop production

\begin{tabular}{lll}
\hline Activity & Cost & Value \\
\hline Establishment & Labour for ground preparation $\left(€ \mathrm{ha}^{-1}\right)$ & 280 \\
& Labour for marking out $\left(€ \mathrm{ha}^{-1}\right)$ & 135 \\
& Labour for weeding $\left(€ \mathrm{ha}^{-1}\right)$ & 6 \\
& Labour for planting $(€$ per tree) & 2 \\
& Cost of plant $(€$ per tree) & 16 \\
& Cost of individual tree protection $($ sprays + labour $)(€$ per tree) & 2.75 \\
& Fertiliser application $($ fertilizer + labour $)(€$ per tree) & 0.5 \\
& Cost of harvest $\left(€ \mathrm{t}^{-1}\right)$ & 540 \\
Maintenance & Labour for weeding $(€$ per tree) & 0.15 \\
& Labour for pruning and removal of prunings $(€$ per tree) & 0.08 \\
\hline
\end{tabular}

\begin{tabular}{|c|c|c|c|c|}
\hline & Component & Rapeseed & Barley & Maize \\
\hline \multirow[t]{3}{*}{ Revenue } & Area payment $\left(€ \mathrm{ha}^{-1}\right)$ & 245 & 245 & 245 \\
\hline & Grain or oilseed $\left(€ \mathrm{t}^{-1}\right)$ & 325 & 140 & 135 \\
\hline & Straw $\left(€ \mathrm{t}^{-1}\right)$ & na & 25 & 31 \\
\hline \multirow[t]{11}{*}{ Costs } & Seed price $\left(€ \mathrm{~kg}^{-1}\right)$ & 15 & 0.4 & 8 \\
\hline & Seed rate $\left(\mathrm{kg} \mathrm{ha}^{-1}\right)$ & 5 & 200 & 20 \\
\hline & Cost of $\mathrm{N}$ fertiliser $\left(€ \mathrm{~kg}^{-1} \mathrm{~N}\right)$ & 1.9 & 1.6 & 1.87 \\
\hline & $\mathrm{N}$ fertiliser rate $\left(\mathrm{kg} \mathrm{N} \mathrm{ha}^{-1}\right)$ & 105 & 95 & 155 \\
\hline & Cost of $\mathrm{P}$ fertiliser $\left(€ \mathrm{~kg}^{-1} \mathrm{P}\right)$ & 1.3 & 0.95 & 1.54 \\
\hline & $\mathrm{P}$ fertiliser rate $\left(\mathrm{kg} \mathrm{P} \mathrm{ha}^{-1}\right)$ & 150 & 100 & 130 \\
\hline & Cost of $\mathrm{K}$ fertiliser $\left(€ \mathrm{~kg}^{-1} \mathrm{~K}\right)$ & 0.93 & 0.83 & 1 \\
\hline & $\mathrm{K}$ fertiliser rate $\left(\mathrm{kg} \mathrm{K} \mathrm{ha}^{-1}\right)$ & 215 & 120 & 250 \\
\hline & Spray price (€ per application) & 80 & 120 & 103 \\
\hline & Spray rate $\left(\mathrm{app} \mathrm{ha} \mathrm{h}^{-1}\right)$ & 1 & 1 & 1 \\
\hline & Machinery $\left(€ \mathrm{ha}^{-1}\right)$ & 200 & 240 & 250 \\
\hline
\end{tabular}

na not applicable

and assignable fixed costs $\left(A_{t}\right)$ of production which are specified for each year $(t)$ over a time horizon of $T$ (years) and expressed as a net present values (NPV) using a discount rate $(i)$ to determine the present value of future income flows (Eq. 2);

$N P V=\sum_{t=0}^{t=T} \frac{\left(R_{t}-V_{t}-A_{t}\right)}{(1+i)^{t}}$

The discount rate of $4 \%$ was chosen as reported by European Commission 2014 and used by Graves et al. (2007) and García de Jalón et al. (2018). Cumulative net margins over the assumed rotation were calculated by adding up annual NPV values and payback periods were determined for each system and scenario. 


\section{Results}

Monocrop arable yields

Actual mean yields of grain maize in Croatia in 2013 and 2016 were 6.5 and $8.5 \mathrm{t} \mathrm{ha}^{-1}$; mean yields of barley were $3.8 \mathrm{t} \mathrm{ha}^{-1}$ in 2014 and $4.8 \mathrm{t} \mathrm{ha}^{-1}$ in 2017 , and the mean rapeseed yield was $2.6 \mathrm{t} \mathrm{ha}^{-1}$ in 2015 . The modelled yields of grain maize (8.5 and $9.7 \mathrm{t} \mathrm{ha}^{-1}$ ), barley (4.8 and $4.1 \mathrm{t} \mathrm{ha}^{-1}$ ) and rapeseed $\left(2.8 \mathrm{t} \mathrm{ha}^{-1}\right)$ were broadly similar to the observed yields (Fig. 2) with a strong correlation of 0.954 $(p<0.05)$.

Walnut fruit production in intercropped orchard

The parameterised Yield-SAFE model predicted annual walnut yields (in shell basis) to increase to about $20 \mathrm{~kg}$ per tree by year 20 . By year 20 , the fruit yields in the intercropped and walnut-only system were broadly similar, but the yield per hectare was dependent on the tree density, ranging from $2038 \mathrm{~kg} \mathrm{ha}^{-1}$ with 100 trees ha ${ }^{-1}$ to $3679 \mathrm{~kg} \mathrm{ha}^{-1}$ at a tree density of 170 trees ha $^{-1}$ (Fig. 3).

The model predicted that the arable crops would substantially reduce walnut yields in the initial 10 years (Table 3 ). This effect of crops on trees could be due to underground competition for water since crops can alter and limit water availability to the roots of young trees. Water limitation reduces the growth of trees, which can then delay and reduce fruit yield. However, the predicted walnut yields in intercropped orchard exceeded walnut yields in pure walnut orchard after year 12 for density of 100 trees $^{-1}$ and year 13 and 14 for densities of 135 and 170 trees ha ${ }^{-1}$, respectively (Table 3).

Modelling crop yields in intercropped orchards

With the calibrated crop and walnut parameters, the model was used to predict the effect of the three tree densities on the intercrops yield per total area. Up to the seventh year after planting, the relative crop yields within the intercropping systems were between 82 and $114 \%$ of those in the monoculture system at each of the three tree densities (Fig. 4). However, after year 7 , when trees are well developed and dominant in both aboveground and belowground competition, the predicted relative crop yields were below 70\% (Fig. 4) with the highest intercropping yields predicted at 100 trees ha ${ }^{-1}$ and the lowest at 170 trees $^{-1}$. Among the crop species, grain maize gave the highest predicted relative yields e.g. 1.14 in the first year, and barley resulted in the lowest relative yields. These results are not expected as spring crops, such as grain maize usually result in lower yields than winter crops in intercropped systems. However, it is not impossible for spring crops to achieve such high yields in the first years of intercropping while the trees do not have a large canopy and have no significant competition for

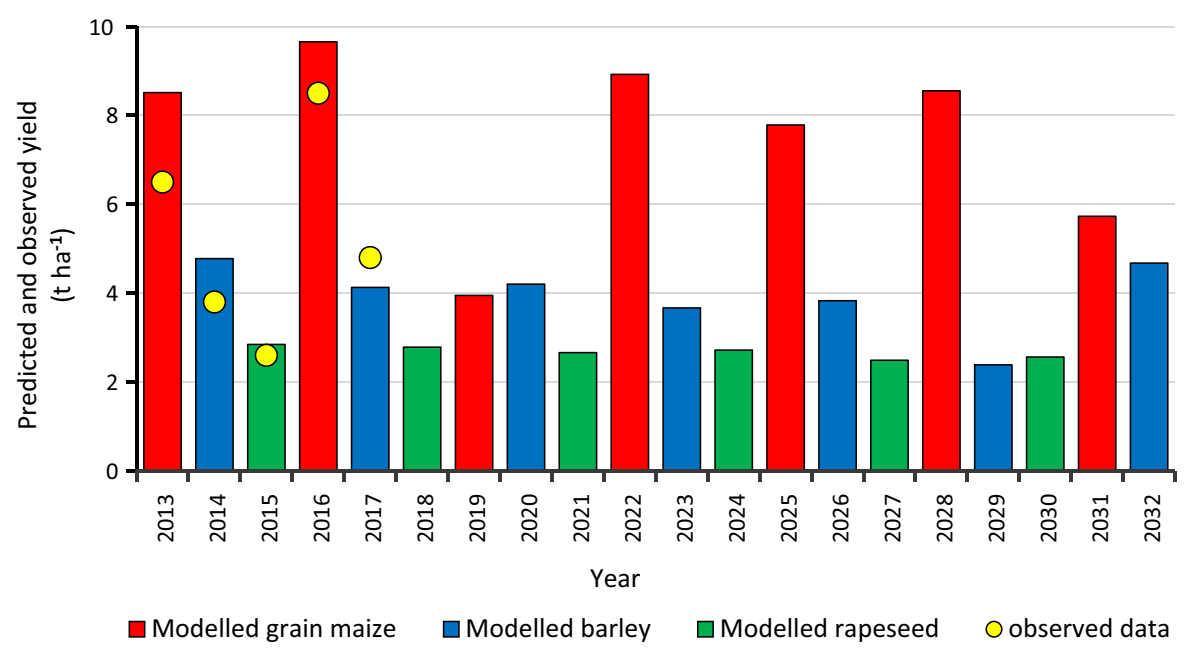

Fig. 2 Modelled (2013-2032) and measured (2013-2017) mean annual crop yields in a grain maize (2013 and 2016), barley (2014 and 2017) and rapeseed (2015) rotation 
Fig. 3 Modelled walnut fruit production for three tree-densities during the first 20 years expressed in kilograms per hectare: $I O$ intercropped orchard, $O$ orchard (170, 135, 100 trees $\mathrm{ha}^{-1}$ )

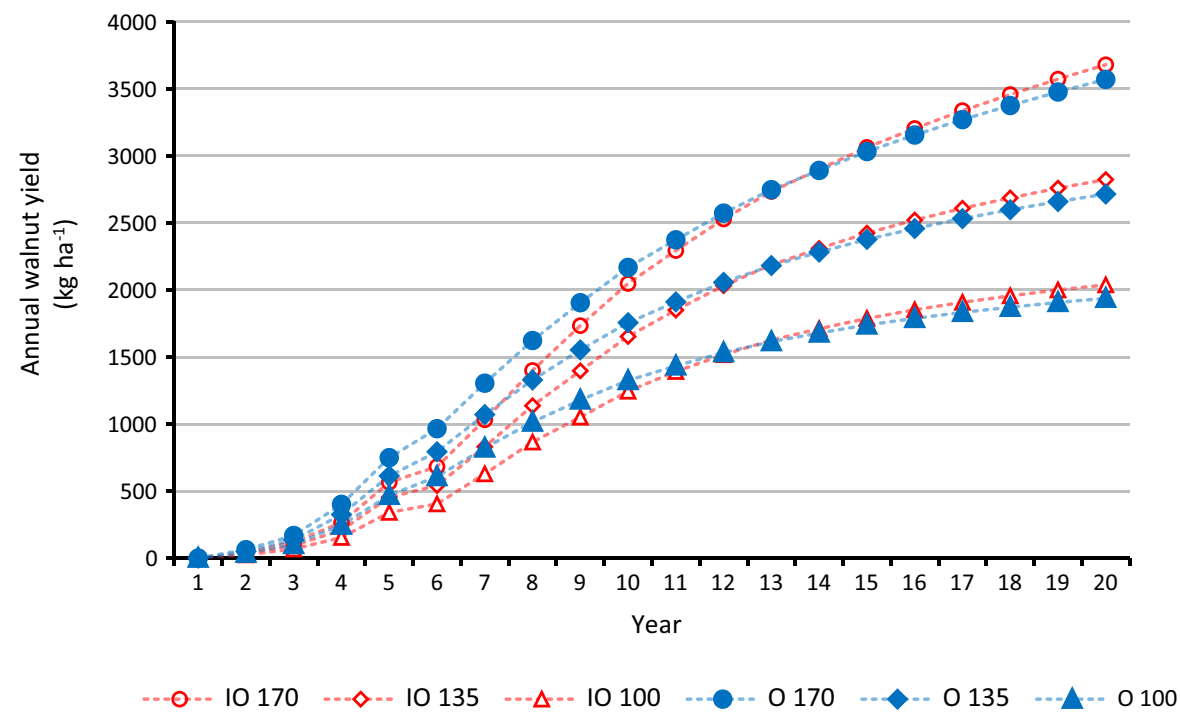

Table 3 Modelled relative walnut yield per hectare of an orchard including intercropping, relative to a non-intercropped orchard, at three densities

\begin{tabular}{|c|c|c|c|c|}
\hline \multirow[t]{2}{*}{ Year } & \multirow[t]{2}{*}{ Crop } & \multicolumn{3}{|l|}{ Tree density } \\
\hline & & 170 trees $\mathrm{ha}^{-1}$ & 135 trees $\mathrm{ha}^{-1}$ & 100 trees $\mathrm{ha}^{-1}$ \\
\hline 1 & Maize & 0.50 & 0.50 & 1.00 \\
\hline 2 & Barley & 0.67 & 0.67 & 0.66 \\
\hline 3 & Oilseed & 0.72 & 0.69 & 0.67 \\
\hline 4 & Maize & 0.66 & 0.64 & 0.63 \\
\hline 5 & Barley & 0.75 & 0.74 & 0.73 \\
\hline 6 & Oilseed & 0.71 & 0.68 & 0.67 \\
\hline 7 & Maize & 0.79 & 0.78 & 0.77 \\
\hline 8 & Barley & 0.86 & 0.86 & 0.85 \\
\hline 9 & Oilseed & 0.91 & 0.90 & 0.89 \\
\hline 10 & Maize & 0.94 & 0.94 & 0.94 \\
\hline 11 & Barley & 0.97 & 0.97 & 0.97 \\
\hline 12 & Oilseed & 0.98 & 0.99 & 0.99 \\
\hline 13 & Maize & 0.99 & 1.00 & 1.01 \\
\hline 14 & Barley & 1.00 & 1.01 & 1.02 \\
\hline 15 & Oilseed & 1.01 & 1.02 & 1.03 \\
\hline 16 & Maize & 1.02 & 1.03 & 1.04 \\
\hline 17 & Barley & 1.02 & 1.03 & 1.04 \\
\hline 18 & Oilseed & 1.02 & 1.03 & 1.05 \\
\hline 19 & Maize & 1.03 & 1.04 & 1.05 \\
\hline 20 & Barley & 1.03 & 1.04 & 1.05 \\
\hline
\end{tabular}

sunlight. As for grain maize, it has deep roots that in the first years of intercropping, while the trees have not yet fully developed their own, have room to spread out and absorb enough nutrients and water.

\section{Land equivalent ratio (LER)}

Using the model it was possible to derive the annual LER for the three density scenarios. The intercropped walnut orchard was assumed to have the same number 
Fig. 4 Predicted relative crop yields for the walnut intercrops at three densities: $G M$ grain maize, $B$ barley, $R S$ Rapeseed (170, 135, 100 trees $\mathrm{ha}^{-1}$ ) calculated per total area

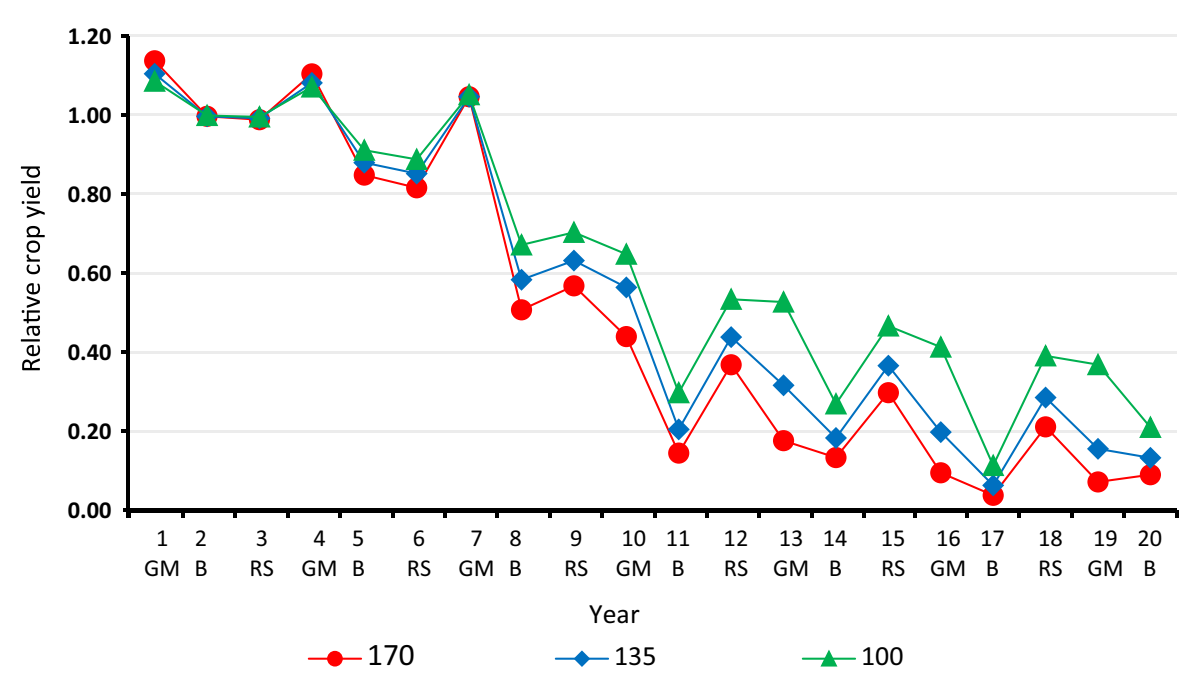

of trees as the control walnut-only orchard. Although the model predicted walnut yields in both the first (1-2 $\left.\mathrm{kg} \mathrm{ha}^{-1}\right)$ and second year (25-64 kg ha ${ }^{-1}$ ), in reality, the walnut does not yield at least the first 2 years. For this reason, we investigated and presented LER starting from year 3. So, in the third year, the predicted LER for the three tree densitities were; 1.71 in the 170 trees ha $^{-1}$ system, 1.68 in the 135 trees $^{-1}$ system and 1.66 in the 100 trees ha $^{-1}$ system. As relative walnut yield was increasing with time (Table 3), crop relative yield decreased significantly (Fig. 4.) which showed an effect on annual LER values. So by year 20, the LER had declined to 1.38 at 170 trees ha $^{-1}, 1.43$ at 135 trees ha $^{-1}$, and 1.53 at 100 trees $\mathrm{ha}^{-1}$.

\section{Net margins of crop production}

The net margin from the crop system includes both the revenue of the main crop and the by-product. Including the revenue from the by-product increases the net margin of the maize and the barley crop; there was no by-product with the rapeseed crop. The highest net margin in the arable system was achieved from the maize crop in year $1\left(353 € \mathrm{ha}^{-1}\right)$ and year 4 $\left(476 € \mathrm{ha}^{-1}\right)$. The least profitable crop was barley. The net margin from the arable component of all silvoarable systems showed substantial losses after year 6 , meaning it was no longer profitable to intercrop in walnut orchard with any of the three tree densities.
Cumulative net margins

The predicted cumulative net margins are discounted future values at a discount rate of $4 \%$. For the arable system in year 20 , the net present value was $2573 € \mathrm{ha}^{-1}$ (Fig. 5). The establishment costs, which were between 1600 and $3500 € \mathrm{ha}^{-1}$, in the walnutonly and walnut intercropped systems, meant that the net margin was negative in the initial years (Fig. 5). Due to more plant material needed, as well as labor, the establishment costs were greater for the 170 tree $\mathrm{ha}^{-1}$ system than the 100 tree ha $^{-1}$ system.

The intercropped system of 100 trees ha ${ }^{-1}$ was predicted to break-even in year 4 and intercropped system of 135 and 170 trees $^{-1}$ in year 5. By contrast, the walnut-only systems were predicted to break-even 1 year later; orchard with 100 trees ha $^{-1}$ in year 5 , and orchards with 135 or 175 trees ha $^{-1}$ in year 6.

After 6 years, the continued cropping of an intercrop started to substantially reduce the cumulative net margin of the intercropped systems, to the extent that the walnut-only systems started to become more profitable. Because arable cropping below the trees was no longer profitable after year 6 , the net margin of the silvoarable system can be improved by stopping intercropping in year 7 . The results showed that stopping intercropping after year 6 and maintaining an orchard for the remaining 14 years provided a greater cumulative net margin than intercropping for full 20 years and the sole walnut orchard systems at equivalent tree densities. The greatest NPV 


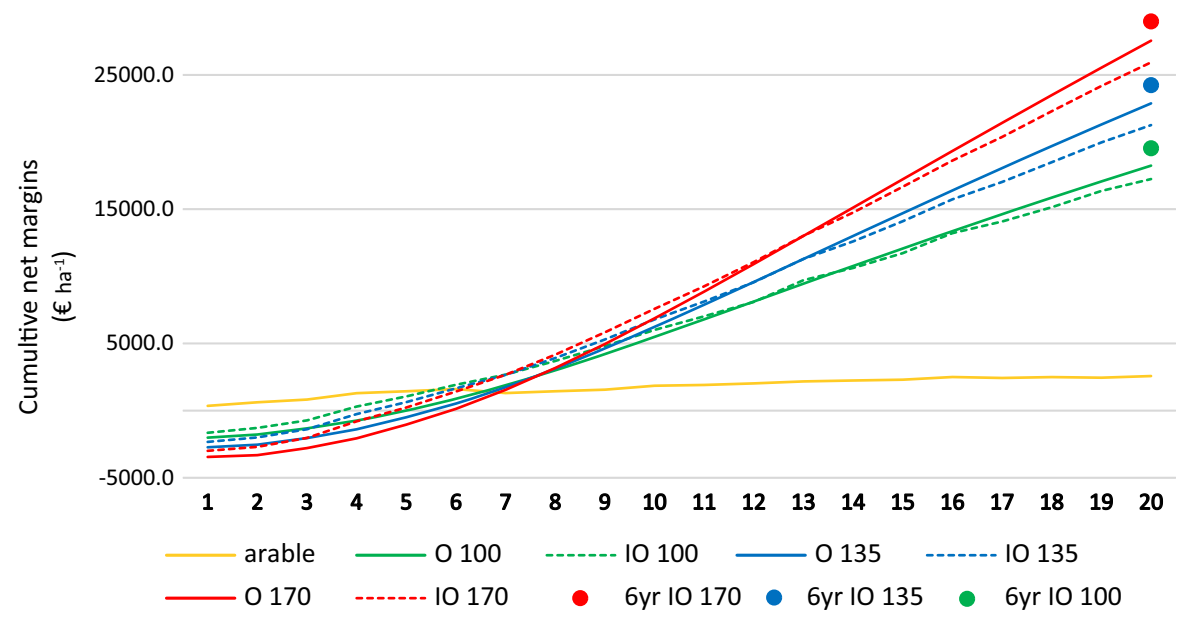

Fig. 5 Discounted (4\%) cumulative net margins of the arable system, and the walnut-only and walnut-intercropping systems with a tree density of 170 trees $\mathrm{ha}^{-1}$ (crop area in the intercropped orchard: 0.75 ), 135 trees $^{-1} a^{-1}$ (crop area in the

$\left(28,986 € \mathrm{ha}^{-1}\right)$ was obtained for the 6-years intercroped orchard at 170 trees ha $^{-1}$ (Table 4).

\section{Discussion}

To the best of our knowledge this is the first attempt to use bio-economic models to compare the yields and net margins associated with nut production in Croatia from intercropped and sole orchard systems at equivalent tree densities, as well as the first application of Farm-SAFE model where walnut fruit production is the main objective of establishing intercropped system with walnut. The results are discussed in terms of the biophysical modelling of tree and crop yields and the financial implications, which can serve as an insight into the possibilities of establishing silvoarable intercropped orchard: 0.80 ), 100 trees $\mathrm{ha}^{-1}$ (crop area in the intercropped orchard: 0.83 ), $O$ orchard, $I O$ intercropped orchard $\left(170,135,100\right.$ trees $\left.h^{-1}\right)$ over 20 years and intercropped systems stopped when no longer profitable—after 6 years

practice for Croatian farmers, as well as farmers in Eastern Europe area with the same climatic and economic conditions.

The Yield-SAFE model predicted the highest walnut yields per hectare for walnut-only and intercropped system with a tree density of 170 rather than those with 135 or 100 trees $^{-1}$ (Fig. 3). However, the increasing competition between the trees for light and water meant that individual tree fruit production $\left(\mathrm{kg} \mathrm{tree}^{-1}\right)$ was greatest in orchards at 100 trees ha $^{-1}$. Similar effects at high tree densities, resulting in greater light and water competition, and hence lower timber volumes per tree have also been reported by Graves et al. (2010). The simulation also showed that the arable crops would initially reduce annual nut production (Table 3 ), most likely by limiting available water for tree roots and therefore limiting its growth,

Table 4 Discounted (4\%) cumulative net margins of the walnut orchard, the intercropped orchard, and the orchard intercropped for the first 6 years, calculated over 20 years $\left(€ \mathrm{ha}^{-1}\right)$

\begin{tabular}{llll}
\hline Tree density & \multicolumn{2}{l}{ Net present value $\left(€ \mathrm{ha}^{-1}\right)$} \\
\cline { 2 - 4 } & Walnut orchard & Intercropped orchard for 20 years & Intercropped orchard until crop component is profitable \\
\hline 170 trees ha $^{-1}$ & 27,551 & 25,936 & 28,986 \\
135 trees ha $^{-1}$ & 22,880 & 21,263 & 24,240 \\
100 trees ha $^{-1}$ & 18,243 & 17,244 & 19,539 \\
\hline
\end{tabular}


as seen in research by Burgess et al. (1996). However as the trees increased in size and became dominant species in the competition for resources, the model predicted that the annual nut yields in intercropped orchards would no longer be affected by crops and would even exceed nut yields in walnut-only systems, however this difference was not statistically significant.

The Yield-SAFE model predicted high relative crop yields in early years of intercropped systems for maize (1.05-1.14 in year 1, 4 and 7). Although unexpected, such yields are not impossible and have been reported earlier by other authors (Burgess et al. 2004; Seserman et al. 2019). In traditional Dehesa systems in Spain and Portugal vicinity of trees showed a beneficial effect on crop growth (Moreno 2008; GeaIzquierdo et al. 2009). Since maize is a spring crop, summer droughts can result with decrease in maize yields. Microclimatic conditions in orchards, in terms of increased humidity compared to an open field, might have the beneficial effect on maize yields in early years while enough light was still available for the crop. Besides these high relative maize yields, the model predicted a steady decline in relative arable crop yields as the walnut trees grew-they dropped below 0.7 after year 7 (Fig. 4). Within the model, this decline occurs due to increasing competition for water and light. Similarly, Newman (2006) in trials from Buckinghamshire and Essex reported that arable yields within a poplar agroforestry system could be maintained for 10 years until tree competition became too severe. The simulations demonstrated that the greatest decline in crop yields occurred at the greatest tree density of 170 trees $^{-1}$. Similarly, results from previous studies showed a greater decrease in relative crop yields in silvoarable systems at 113 trees $\mathrm{ha}^{-1}$ than at 50 trees ha $^{-1}$ (Graves et al. 2007).

Overall, the calculated LER of the intercropped systems over the full 20 years of intercropping the LER was between 1.38 for 170 trees ha $^{-1}$ and 1.53 for 100 trees $\mathrm{ha}^{-1}$. These full-rotation values are similar to values of between 1.00 and 1.40 reported from modelling studies for timber trees in other European countries undertaken by Graves et al. (2007).

The financial analysis demonstrated that the arable system produced a positive and relatively consistent cashflow over 20 years (Fig. 5), whereas the agroforestry and the tree-only system started with substantial losses, which were only reversed as the walnut system started to produce walnuts. The initial costs of orchard establishment were $1600-3500 € \mathrm{ha}^{-1}$ depending on the tree density. However, over a period of 20 years, the predicted returns from the walnut systems were significantly greater than arable cropping. This coincides with the current interest in establishing walnut orchards in Croatia. It should be noted that the above financial analysis ignores the possibility of catastrophic or partial damage to the walnut system through fire, vandalism, or pest damage. Incorporating such effects into a financial analysis is difficult, but it should be part of the consideration before any investment decision.

During the first 6 years of the walnut plantation, intercropping was predicted to increase the net margin. However, continued cropping beyond this period resulted in financial losses as crops could not reach satisfactory yield and income in silvoarable systems. In practice, as soon as crop production in the intercropped system becomes unprofitable, a farmer would stop intercropping. With this scenario of intercropping stopped in year 7 , the system resulted in a greater net margin over 20 years than the walnutonly system (Table 4), which showed that this silvoarable practice is a profitable option for transitioning from arable farming to walnut nut production. However, in the most intensive system, with a density of 170 trees ha $^{-1}$, which was the most profitable out of all densities, the difference in the net margin between the walnut-only system $\left(27,551 € \mathrm{ha}^{-1}\right)$ and system with intercropping for the first 6 years $\left(28,986 € \mathrm{ha}^{-1}\right)$ is only $€ 1435 \mathrm{ha}^{-1}$. It remains arguable whether this financial benefit is sufficient for a farmer to practice intercropping, particularly if the intercropping results in additional administrative and managerial work. This analysis has focused solely on the agronomic and financial analysis of the systems. In practice, growing trees rather than arable crops can provide ecological benefits such as increased carbon storage, reduced water pollution, and enhanced biodiversity than can be ascribed financial values (García de Jalón et al. 2018). This can greatly increase the social value of tree-based systems.

\section{Conclusion}

The use of the Yield-SAFE and Farm-SAFE agroforestry simulation models highlights some of the 
opportunities and challenges associated with the possibility of intercropping in the newly established walnut orchards. Here, it highlighted that beyond the high grain maize yields in initial years, the yield of an intercropped arable crop would be less than that in a control arable field, and that the crop could also restrict the productivity of the walnut trees. However, it also showed that intercropping systems could have a very high land equivalent ratio in the initial years of planting and that even after 20 years of intercropping, the predicted LER was above 1 . These LERs indicate that growing walnut trees and crops in the intercropped system is more productive than growing them separately. Intercropping for the first 6 years provided financial benefit, allowing the offset of high orchard establishment costs by providing the additional revenue from the crops. However, intercropping for full 20 years showed no advantage over cultivating pure walnut orchard. The analysis also indicated that a density of 170 rather than 100 trees $^{-1} \mathrm{a}^{-1}$ resulted in the highest net margins for each year of a 20 -year rotation.

Acknowledgements This study is funded by the Croatian Science Foundation project: Intercropping of wood species and agricultural crops as an innovative approach in agroecosystems (7103) and ERASMUS exchange program for staff.

Open Access This article is licensed under a Creative Commons Attribution 4.0 International License, which permits use, sharing, adaptation, distribution and reproduction in any medium or format, as long as you give appropriate credit to the original author(s) and the source, provide a link to the Creative Commons licence, and indicate if changes were made. The images or other third party material in this article are included in the article's Creative Commons licence, unless indicated otherwise in a credit line to the material. If material is not included in the article's Creative Commons licence and your intended use is not permitted by statutory regulation or exceeds the permitted use, you will need to obtain permission directly from the copyright holder. To view a copy of this licence, visit http://creativecommons.org/licenses/by/4.0/.

\section{References}

Ahmad N, Singh S, Bakshi M, Mir H (2018) Walnut. In: Dhillon WS (ed) Fruit production in India. Narendra Publishing House, New Delhi, pp 661-672

Burgess PJ, Rosati A (2018) Advances in European agroforestry: results from the AGFORWARD project. Agrofor
Syst 92(4):801-810. https://doi.org/10.1007/s10457-0180261-3

Burgess PJ, Stephens W, Anderson G, Durston J (1996) Water use by a poplar wheat agroforestry system. Asp Appl Biol 44:129-136

Burgess PJ, Incoll LD, Corry DT, Beaton A, Hart BJ (2004) Poplar (Populus spp) growth and crop yields in a silvoarable experiment at three lowland sites in England. Agrofor Syst 63(2):157-169. https://doi.org/10.1007/ s10457-004-7169-9

Cardinael R, Chevallier T, Cambou A, Béral C, Barthès BG, Dupraz C, Durand C, Kouakoua E, Chenu C (2017) Increased soil organic carbon stocks under agroforestry: a survey of six different sites in France. Agric Ecosyst Environ 236:243-255. https://doi.org/10.1016/j.agee. 2016.12.011

Cong WF, Hoffland E, Li L, Six J, Sun JH, Bao XG, Zhang FS, van der Werf W (2015) Intercropping enhances soil carbon and nitrogen. Glob Change Biol 21(4):1715-1726. https:// doi.org/10.1111/gcb. 12738

Croatian Agricultural and Forestry Advisory Service (2018) Katalog kalkulacija poljoprivredne proizvodnje 2018. Retrieved from: https://www.savjetodavna.hr/product/ katalog-kalkulacija-poljoprivredne-proizvodnje/

Croatian Bureau of Statistics (2018) Statistical yearbook of the Republic of Croatia. pp 1-21. Retrieved from https://www. dzs.hr/Eng/Publication/stat_year.htm

den Herder M, Moreno G, Mosquera-losada RM, Palma JHN, Sidiropoulou A, Santiago Freijanes JJ, Crous-Duran J, Paulo JA, Tomé M, Pantera A, Papanastasis VP, Mantzanas K, Pachana P, Papadopoulos A, Plieninger T, Burgess PJ (2017) Current extent and stratification of agroforestry in the European Union. Agric Ecosyst Environ 241:121-132. https://doi.org/10.1016/j.agee.2017.03.005

European Commission (2014) Guide to cost-benefit analysis of investment projects: economic appraisal tool for cohesion policy 2014-2020. Publications Office of the European Union, Brussels. https://doi.org/10.2776/97516

García de Jalón S, Graves A, Palma JHN, Williams A, Upson M, Burgess PJ (2018) Modelling and valuing the environmental impacts of arable, forestry and agroforestry systems: a case study. Agrofor Syst 92(4):1059-1073. https:// doi.org/10.1007/s10457-017-0128-z

Gea-Izquierdo G, Montero G, Cañellas I (2009) Changes in limiting resources determine spatio-temporal variability in tree-grass interactions. Agrofor Syst 76(2):375-387. https://doi.org/10.1007/s10457-009-9211-4

Graves AR, Burgess PJ, Palma JHN, Herzog F, Moreno G, Bertomeu M, Dupraz C, Liagre F, Keesman K, van der Werf W, Koeffeman De Nooy A, van den Briel JP (2007) Development and application of bio-economic modelling to compare silvoarable, arable, and forestry systems in three European countries. Ecol Eng 29(4):434-449. https:// doi.org/10.1016/J.ECOLENG.2006.09.018

Graves AR, Burgess PJ, Palma JHN, Keesman KJ, van der Werf W, Dupraz C, Van Keulen H, Herzog F, Mayus M (2010) Implementation and calibration of the parameter-sparse Yield-SAFE model to predict production and land equivalent ratio in mixed tree and crop systems under two contrasting production situations in Europe. Ecol Model 
221(13-14): 1744-1756. ecolmodel.2010.03.008

https://doi.org/10.1016/j.

Graves AR, Burgess PJ, Liagre F, Terreaux JP, Borrel T, Dupraz C, Palma JHN, Herzog F (2011) Farm-SAFE: the process of developing a plot- and farm-scale model of arable, forestry, and silvoarable economics. Agrofor Syst 81(2):93-108. https://doi.org/10.1007/s10457-010-9363-2

Graves AR, Burgess PJ, Liagre F, Dupraz C (2017) Farmer perception of benefits, constraints and opportunities for silvoarable systems: preliminary insights from Bedfordshire, England. Outlook on Agric 46(1):74-83. https://doi. org/10.1177/0030727017691173

Japundžić M (2017) Podizanje nasada oraha na OPG Japundžić. Bachelor's thesis, University in Požega. Retrieved from https://repozitorij.vup.hr/islandora/object/vup\%3A710

Moreno G (2008) Response of understorey forage to multiple tree effects in Iberian dehesas. Agric Ecosyst Environ 123(1-3):239-244. https://doi.org/10.1016/j.agee.2007. 04.006

Newman SM (2006) Agronomic and economic aspects of walnut agroforestry in the UK. Acta Hortic 705:65-67. https:// doi.org/10.17660/ActaHortic.2005.705.6

Ong CK, Kho RM (2015) A framework for quantifying the various effects of tree-crop interactions. Tree Crop Interact Agrofor Chang Clim. https://doi.org/10.1079/97817806 45117.0001

Orah (2009) Ministarstvo poljoprivrede—uprava za stručnu podršku razvoju poljoprivrede i ribarstva. Retrived from https://www.savjetodavna.hr/2009/04/10/orah/

Orah - značajna voćna vrsta (2007) Ministarstvo poljoprivrede-uprava za stručnu podršku razvoju poljoprivrede i ribarstva. Retrived from https://www. savjetodavna.hr/2007/05/10/orah-znacajna-vocna-vrsta/

Ozkan G, Koyuncu MA (2005) Physical and chemical composition of some walnut (Juglans regia L.) genotypes grown in Turkey. Grasas Aceites. https://doi.org/10.3989/gya. 2005.v56.i2.122

Palma JHN (2017) Clipick—climate change web picker. A tool bridging daily climate needs in process based modelling in forestry and agriculture. For Syst 26(1):1-4. https://doi. org/10.5424/fs/2017261-10251

Palma JHN, Graves AR, Burgess PJ, van der Werf W, Herzog F (2007a) Integrating environmental and economic performance to assess modern silvoarable agroforestry in Europe. Ecol Econ 63(4):759-767. https://doi.org/10.1016/j. ecolecon.2007.01.011

Palma JHN, Graves AR, Bunce RGH, Burgess PJ, de Filippi R, Keesman KJ, Van Keulen H, Liagre F, Mayus M, Moreno G, Reisner Y, Herzog F (2007b) Modeling environmental benefits of silvoarable agroforestry in Europe. Agric Ecosyst Environ 119(3-4):320-334. https://doi.org/10.1016/j. agee.2006.07.021

Palma JHN, Crous-Duran J, Graves AR, Garcia de Jalon S, Upson M, Oliveira TS, Paulo JA, Ferreiro-Domínguez N, Moreno G, Burgess PJ (2018) Integrating belowground carbon dynamics into Yield-SAFE, a parameter sparse agroforestry model. Agrofor Syst 92(4):1047-1057. https://doi.org/10.1007/s10457-017-0123-4

Pantera A, Burgess PJ, Mosquera-Losada MR, Moreno G, López-Díaz ML, Corroyer N, McAdam J, Rosati A, Papadopoulos AM, Graves AR, Rigueiro-Rodríguez A, Ferreiro-Domínguez N, Fernández-Lorenzo JL, GonzálezHernández MP, Papanastasis VP, Mantzanas K, van Lerberghe P, Malignier N (2018) Agroforestry for high value tree systems in Europe. Agrofor Syst 92(4):945-959. https://doi.org/10.1007/s10457-017-0181-7

Pardon P, Reubens B, Reheul D, Mertens J, De Frenne P, Coussement T, Janssens P, Verheyen K (2017) Trees increase soil organic carbon and nutrient availability in temperate agroforestry systems. Agric Ecosyst Environ 247:98-111. https://doi.org/10.1016/j.agee.2017.06.018

Quinkenstein A, Wöllecke J, Böhm C, Grünewald H, Freese D, Schneider BU, Hüttl RF (2009) Ecological benefits of the alley cropping agroforestry system in sensitive regions of Europe. Environ Sci Policy 12(8):1112-1121. https://doi. org/10.1016/j.envsci.2009.08.008

Seserman DM, Freese D, Swieter A, Langhof M, Veste M (2019) Trade-off between energy wood and grain production in temperate alley-cropping systems: an empirical and simulation-based derivation of land equivalent ratio. Agriculture (Switzerland) 9(7):147. https://doi.org/10. 3390/agriculture9070147

The Council of the European Union (2005) Coucil Regulation (EC) No. 1698/2005 of 20 September 2005 on support for rural development by the European Agricultural Fund for Rural Development (EAFRD). Official Journal of the European Union, L 277 (21.10.2005.):1-40. https://eurlex.europa.eu/legal-content/EN/TXT/?qid= 1570006564210\&uri=CELEX:32005R1698

Torralba M, Fagerholm N, Burgess PJ, Moreno G, Plieninger T (2016) Do European agroforestry systems enhance biodiversity and ecosystem services? A meta-analysis. Agric Ecosyst Environ 230:150-161. https://doi.org/10.1016/J. AGEE.2016.06.002

Tsonkova P, Böhm C, Quinkenstein A, Freese D (2012) Ecological benefits provided by alley cropping systems for production of woody biomass in the temperate region: a review. Agrofor Syst 85(1):133-152. https://doi.org/10. 1007/s10457-012-9494-8

van der Werf W, Keesman K, Burgess PJ, Graves AR, Pilbeam D, Incoll LD, Metselaar K, Mayus M, Stappers R, Van Keulen H, Palma JHN, Dupraz C (2007) Yield-SAFE: a parameter-sparse, process-based dynamic model for predicting resource capture, growth, and production in agroforestry systems. Ecol Eng 29(4):419-433. https://doi.org/ 10.1016/j.ecoleng.2006.09.017

Publisher's note Springer Nature remains neutral with regard to jurisdictional claims in published maps and institutional affiliations. 